\title{
Sentinels to climate change. The need for monitoring at South Africa's Subantarctic laboratory
}

AUTHORS:

Isabelle J. Ansorge ${ }^{1}$

Jonathan V. Durgadoo²

Anne M. Treasure ${ }^{1}$

\section{AFFILIATIONS:}

${ }^{1}$ Department of Oceanography, Marine Research Institute (Ma$\mathrm{Re})$, University of Cape Town, Cape Town, South Africa

${ }^{2}$ GEOMAR Helmholtz Centre for Ocean Research, Kiel, Germany

\section{CORRESPONDENCE TO: \\ Isabelle Ansorge}

EMAIL:

Isabelle.Ansorge@uct.ac.za

\section{POSTAL ADDRESS:}

Department of Oceanography, Marine Research Institute (Ma-Re), University of Cape Town, Private Bag, Rondebosch 7701 , South Africa

\section{KEYWORDS:}

Prince Edward Islands; Subantarctic Front; Antarctic Circumpolar Current; climate change; oceanography

\section{HOW TO CITE:}

Ansorge IJ, Durgadoo JV, Treasure AM. Sentinels to climate change. The need for monitoring at South Africa's Subantarctic laboratory. S Afr J Sci. 2014;110(1/2), Art. \#a0044, 4 pages. http://dx.doi. org/10.1590/sajs.2014/a0044
Subantarctic islands form ideal sentinels to climate change. These islands support terrestrial and marine ecosystems that are relatively simple and extremely sensitive to perturbations. ${ }^{1}$ They provide an ideal natural laboratory for studying how ecosystems respond to a changing climate in the Southern Ocean. Initial studies ${ }^{1}$ and subsequent analyses ${ }^{2,3}$ at the Prince Edward Islands in the Indian sector of the Southern Ocean have all shown that there has been a climatological rise of $>1{ }^{\circ} \mathrm{C}$ in the sea surface temperature since 1949. Mirrored to this rise is a decrease in rain, an increase in extreme events, an increase in winds from the warmer sector in the northwest, and annual sunshine hours have risen by $3.3 \mathrm{~h}$ since the $1950 \mathrm{~s}^{1,2,4}$ It has been proposed ${ }^{5}$ that climate changes reported at the Prince Edward Islands correspond in time to a southward shift of the Antarctic Circumpolar Current (ACC) and in particular its frontal systems the Subantarctic Front (SAF) and the Antarctic Polar Front (APF), between which the islands lie (Figure 1). The Prince Edward Islands, like many other oceanic islands within the Southern Ocean, are seasonally characterised by vast populations of marine organisms and a diversity and abundance of seabirds that use the islands as breeding grounds. ${ }^{6,7}$ It is estimated that the islands support over 5 million breeding pairs of top predators including seabirds, penguins and seals during the peak breeding season. ${ }^{7}$ The energy necessary to sustain these top predators is derived from the close interaction between the oceanic environment and the islands themselves. Changes in the intensity and geographic position within these frontal systems are likely to coincide with dramatic changes in the distribution of species and total productivity within the Southern Ocean. Long-term research in both the offshore and near-shore environments of the Prince Edward Islands is critical if the mechanisms needed to sustain high concentrations of marine life in a changing environment are to be better understood and conserved. If ecosystems are pushed beyond certain thresholds or tipping points, there is a high risk of dramatic biodiversity loss and accompanying degradation of a broad range of ecosystem services. ${ }^{8}$ Furthermore, a real threat brought on by a warmer climate will be the increase in ease in which pristine Subantarctic islands such as the Prince Edward Islands can be invaded by alien species. ${ }^{1}$

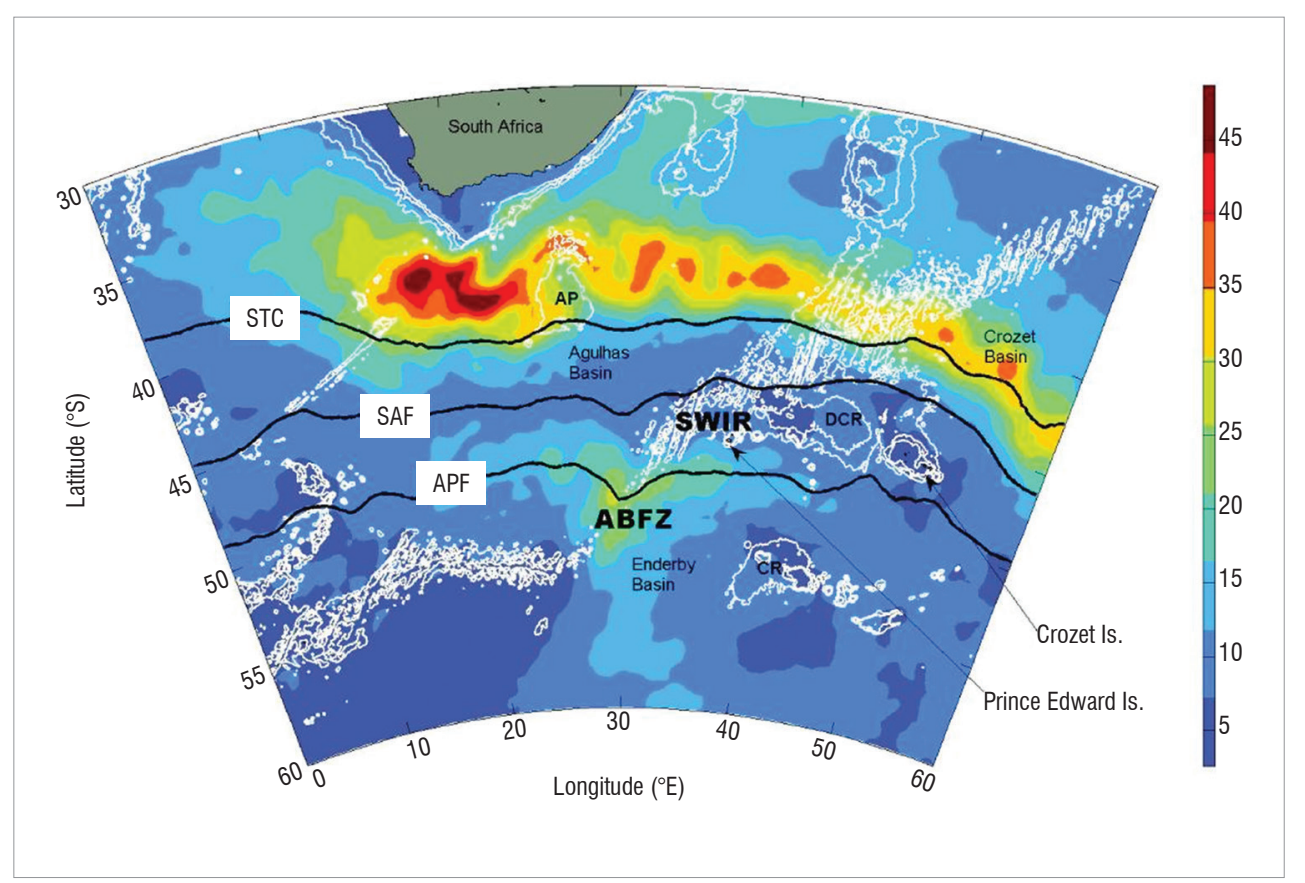

Source: Figure courtesy of Durgadoo et al..$^{10}$

Figure 1: The root mean square in sea level anomaly $(\mathrm{cm})$ calculated from a 13-year record of altimetry products. Two broad regions of variability are observed in the African sector of the Southern Ocean: the Agulhas regime (comprising the Agulhas Current, the Agulhas Retroflection, the Agulhas Return Current and the Subtropical Convergence) and the South-West Indian Ridge (SWIR), a separate region to the south. Bathymetric contours $(-3000 \mathrm{~m},-2000 \mathrm{~m},-1000 \mathrm{~m})$ are overlain in white. The average positions of the three major fronts associated with the Antarctic Circumpolar Current are also shown: the Subtropical Convergence (STC), the Subantarctic Front (SAF) and the Antarctic Polar Front (APF). The Andrew Bain Fracture Zone (ABFZ) is shown as the core of eddy variability. The Del Cano Rise (DCR) lies to the east of the Prince Edward Islands.

Recent observations by the International Programme on the State of the Ocean ${ }^{9}$ have highlighted concerns that the cumulative impacts on the ocean are greater than previously thought and the need to effectively manage fragile ecosystems is now critical. It is likely that global climate change may in the future become associated with the disruption of the 'life support system of the Prince Edward Islands' 6 and further investigations integrating offshore dynamics with the near-shore circulation are required to understand better what impact these changes will have on the system as a whole, and at what rate. On 9 April 2013, the Minister of Water and Environmental Affairs, Edna
(C) 2014. The Authors. Published under a Creative Commons Attribution Licence. 
Molewa, declared the Prince Edward Islands a marine protected area (MPA). The new MPA is intended to contribute to the protection of unique species, habitats and ecosystem processes. It will provide a scientific blueprint that can advise future management in understanding better the impact climate change is having on the Southern Ocean. We highlight the importance of long-term oceanographic research at the Prince Edward Islands if the mechanisms needed to sustain total productivity in a changing environment are to be better understood and the objectives of this newly constituted MPA are to be realised.

\section{Offshore environment: Ocean corridors}

Hydrographic data collected during the recent South African National Antarctic Programme (SANAP)-funded Marion Island Offshore Study (MIOS), Southern Ocean Climate and Biodiversity (SOCAB) and Dynamics of Marion Island's Impacts on the Marine Ecosystem (DEIMEC) programmes ${ }^{10}$ have shown that the ecosystem of the Prince Edward Islands benefits substantially from their location immediately downstream of an eddy corridor (Figure 1). Past investigations ${ }^{11,12}$ have shown that the advection of eddies between the Subantarctic and Antarctic produce meridional heat and salt fluxes that balance much of the ocean-atmosphere exchange across the ACC. If the assumption is correct that a part of this flux comes about through mesoscale eddies, then their quantification at regions where mesoscale turbulence is high may be crucial. Recent studies have shown that since the 1950s, the ACC has warmed with possible shifts in frontal features between $50 \mathrm{~km}$ and $70 \mathrm{~km} .13,14$ The impact this migration may have on the Prince Edward Islands ecosystem over the next century is indeed complex. We speculate that wind stress can induce changes in the intensity and frequency of the Southern Ocean eddy field. In short, an increase in the poleward eddy flux can be attributed to the strengthening westerly wind belt, which in turn has been shown to contribute to the warming of the Southern Ocean ${ }^{13,15}$ Closer examination of Gille's data set suggests these trends occur directly south of each band of high eddy kinetic energy the South-West Indian Ridge being one such example (Figure 1). These eddies move into the inter-island region and have been shown ${ }^{16}$ to carry with them organisms from their region of origin, suggesting that the near-shore waters of the islands have a more diverse spectrum of biota than one would normally expect from a Subantarctic island. Changes in the intensity and geographic position within these frontal systems are likely to coincide with dramatic changes in the distribution of species and total productivity within the Southern Ocean. The impact that a longterm shift in the SAF may have on the near-shore dynamics provokes an interesting discussion.

\section{Near-shore environment: A through-flow system?}

The Prince Edward Islands are seasonally characterised by dense populations of top predators ${ }^{6}$; subsequently, any changes in the frontal dynamics, either in the vicinity of these islands or further afield, may have strong implications on their near-shore foraging behaviour. In addition to the eddy corridor there is growing evidence that the geographical position of the SAF in the proximity of the Prince Edward Islands plays an important role in defining the short-term local macro- and mesoscale oceanographic conditions. ${ }^{17,18}$ Previous investigations have shown that when the SAF lies far north of the islands, the interaction between the ACC and the island group results in water retention over the inter-island region which encourages algal blooms. ${ }^{19}$ During these periods, signature Antarctic species dominate and suggest that water masses typical of modified Antarctic surface water prevail. In contrast, when the SAF meanders southwards in closer proximity to the islands, advection forces prevail and a flow-through system associated with a long-term decline in the frequency of phytoplankton blooms is observed. ${ }^{20,21}$ Recent decline in stable isotope carbon values of the bottom-dwelling shrimp Nauticaris marionis indirectly postulates a decrease in the occurrence of bloom conditions in the inter-island region between the 1980s and 2000s.,22 Mirrored to these findings, there have been increases in the population sizes of offshore feeding land-based predators, such as wandering and grey-headed albatrosses ${ }^{23}$ and Subantarctic and Antarctic fur seals ${ }^{24}$, which may be a result of a decrease in foraging distances from the
Prince Edward Islands. In direct contrast, it appears that the populations of inshore predators feeding on Nauticaris marionis - such as Gentoo and Rockhopper penguins and Crozet shags ${ }^{25-28}$ - have decreased. The decline in the abundances of predators that rely heavily on prey inhabiting the inshore system of the islands suggests an indirect effect of climate change on prey availability. ${ }^{5}$ Climate models suggest a restructuring of the ACC under changing westerly winds, such that its associated frontal systems display an average southward shift. ${ }^{14}$

\section{Ocean monitoring as a tool for marine protected areas}

Separating short-term natural variability through eddy shedding from the long-term southward migration of the ACC remains a key challenge. In-situ long-term oceanographic measurements remain sparse in time and space because of ongoing logistical and cost constraints of marine research in the Southern 0cean. ${ }^{29}$ The need to effectively monitor the long-term change in the position and velocity associated with the ACC in relation to the island group through dedicated research programmes is now critical. On 9 April 2013, the Minister of Water and Environmental Affairs, Edna Molewa, declared the Prince Edward Islands an MPA. This new Prince Edward Islands MPA, the first South African offshore MPA, will serve to significantly contribute to global initiatives towards protection of offshore and deep ocean areas. Minister Molewa added30:
The new MPA is intended, among other things, to contribute to the protection of unique species, habitats and ecosystem processes. It will also provide scientific reference points that can inform the future management of the area and to be able to understand better the impacts of climate change on the whole Southern Ocean. It will also contribute to integrated and ecologically sustainable management of marine resources of the area.

It has been shown ${ }^{31}$ that the success of this MPA will be dependent on the ability to nest the region within a broad management framework encompassing the island's exclusive economic zone and its broader region. A key outcome of this policy is that the Prince Edward Islands are reliant on a combination of ecosystem processes that occur within the inter-island region and further afield at the South-West Indian Ridge. It is unclear whether this change is expected to continue and at what rate. However, it may have already promoted long-term changes in land-based top predator populations on the islands, possibly through food-chain modifications. ${ }^{22} \mathrm{~A}$ key recommendation by the MPA committee ${ }^{31}$ to the Ministry is the need to continue studies that

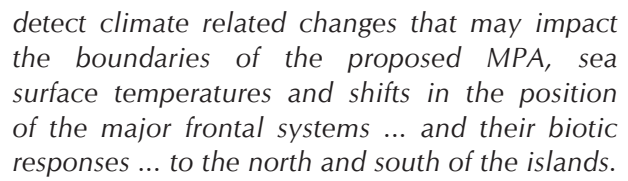
the boundaries of the proposed MPA, sea surface temperatures and shifts in the position of the major frontal systems ... and their biotic responses ... to the north and south of the islands.

This recommendation further mirrors the key focus of the Department of Science and Technology 2018 Grand Challenge which calls for an improved understanding of how the Southern Ocean, and in particular its Subantarctic islands, will respond to climate change through changes in ecosystem function and structure. National long-term environmental monitoring is already supported by government initiatives such as SANAP, the South African Environmental Observation Network and the South African Weather Service. Other organisations also contribute to environmental monitoring but, because such activities need to be long term, 'monitoring and data management may be threatened by the vagaries of funding cycles and changes in research priorities' ${ }^{31}$.

\section{The way forward: Future foci}

The need to integrate near-shore and offshore environments through a series of core objectives is recognised. Our understanding of the eastward passage of eddies extending from the South-West Indian 
Ridge (Figure 1) as well as the implications of a southward migration of the $\mathrm{SAF}^{14}$ has improved through the use of high-resolution ocean models and direct observations through both international (i.e. ARGO, Global Drifter Programme, Aviso) and national (SANAP) programmes. However, interactions of these processes - for instance the impact a change in position of the SAF has on the frequency and intensity of eddy generation at the South-West Indian Ridge - remain unknown. Given recent findings ${ }^{5}$ which show that the southward migration of the SAF is likely to be associated with a long-term decline in phytoplankton blooms, addressing the importance of this biological-physical link is critical. If the SAF is indeed shifting southwards, what impact will this shift have on the inter-island ecosystem in the future? Past investigations have shown that the ability for water to be retained between the islands is dependent on the position of the SAF. Thus, the need to monitor the position of the front in close proximity to the Prince Edward Islands is critical in order to separate the impacts of short-term variability through eddy shedding from the long-term southward migration in response to global climate change. In order to achieve this, a long-term mooring array spanning the inter-island region directed at measuring the position of the SAF, through temperature and velocity profiles, needs to be deployed. Using a full-depth thermistor chain, temperature profiles will highlight both seasonal- and frontal-driven changes in the inter-island region, while velocity profiles from mounted acoustic doppler currrent profilers will provide an insight into the dominant circulation between the islands. It is expected that should the SAF be shifting southwards as inferred by coupled ocean-atmospheric models, ${ }^{14}$ temperature and velocity profiles between the islands will increase over the next decade.

The unique biological diversity of Subantarctic islands provides an ideal environment in which methods can be employed to enhance our ability to predict the impact a changing world has on a fragile ecosystem. The recently launched Prince Edward Island MPA will serve to protect its marine environment by offering South Africa's Subantarctic community a glimpse into the current status quo. It will provide a measure on how ecosystems are currently functioning, which will become increasingly valuable as climate change gradually disorders them. Only when these results become available and are linked with similar long-term biological and biogeochemical observations, will some understanding of the direct role that the SAF has on the near-shore island dynamics and the vulnerability of its ecosystem be fully gained.

\section{Acknowledgements}

The Department of Science and Technology, Department of Environmental Affairs - Antarctic Logistics and Support division and Oceans and Coasts as well as the South African National Antarctic Programme are acknowledged for financial and logistical support. We thank the various captains, officers and crew of the research and supply vessel SA Agulhas and more recently the SA Agulhas // for their endless support and outstanding professionalism over the past decade. The collegial collaboration with biological oceanographers from the Southern Ocean Group at Rhodes University is much appreciated.

\section{References}

1. Smith VR. Climate change in the sub-Antarctic: An illustration from Marion Island. Climatic Change. 2002;52:345-357. http://dx.doi.org/10.1023/ A:1013718617277

2. Mélice J-L, Lutjeharms JRE, Rouault M, Ansorge IJ. Sea-surface temperatures at the sub-Antarctic islands Marion and Gough during the past 50 years. S Afr J Sci. 2003:99:363-366.

3. Ansorge IJ, Durgadoo JV, Pakhomov EA. Dynamics of physical and biological systems of the Prince Edward Islands in a changing climate. Papers and Proceedings of the Tasmanian Royal Society. 2009;143:15-18.

4. Le Roux PC, McGeoch MA. Changes in climate extremes, variability and signature on sub-Antarctic Marion Island. Climatic Change. 2008;86:309 329. http://dx.doi.org/10.1007/s10584-007-9259-y

5. Allen EL, Froneman PW, Durgadoo JV, McQuaid CD, Ansorge IJ, Richoux NB. Critical indirect effects of climate change on sub-Antarctic ecosystem functioning. Ecol Evol. 2013;3(9):2994-3004. http://dx.doi.org/10.1002/ ece3.678
6. Bergstrom D, Chown SL. Life at the front: History, ecology and change on southern ocean islands. Trends Ecol Evol. 1999;14:472-477. http://dx.doi. org/10.1016/S0169-5347(99)01688-2

7. Ryan PG, Bester MN. Pelagic predators. In: Chown SL, Froneman PW, editors. The Prince Edward Islands: Land-sea interactions in a changing ecosystem. Stellenbosch: Sun Press; 2008. p. 121-164.

8. ICSU. Foresight analysis - 2031. International science in 2031 - exploratory scenarios. Paris: International Council for Science; 2011.

9. Rogers AD, Laffoley D d'A International Earth system expert workshop on ocean stresses and impacts: Summary report. Oxford: IPSO; 2011.

10. Durgadoo JV, Ansorge IJ, Lutjeharms JRE. Oceanographic observations of eddies impacting the Prince Edward Islands, South Africa. Antarct Sci. 2010;22(3):211-219. http://dx.doi.org/10.1017/S0954102010000088

11. Gordon AL, Taylor HW. Heat and salt balance within the cold waters of the world ocean, in numerical models of ocean circulation. Washington DC: National Academy of Science; 1975. p. 54-56.

12. De Szoeke R, Levine M. The advective flux of heat by mean geostrophic motions in the Southern Ocean. Deep-Sea Res. 1981;28:1057-1085. http:// dx.doi.org/10.1016/0198-0149(81)90048-0

13. Gille ST. Warming of the Southern Ocean since the 1950s. Science. 2002;295:1275-1277. http://dx.doi.org/10.1126/science.1065863

14. Downes SM, Budnick AS, Sarmiento JL, Farneti R. Impacts of wind stress on the Antarctic Circumpolar Current fronts and associated subduction. Geophys Res Lett. 2011;38:L11605. http://dx.doi.org/10.1029/2011GL047668

15. Meredith $M$, Hogg A. Circumpolar response of the Southern Ocean eddy activity to changes in the Southern Annular Mode. Geophys Res Lett. 2006;33:L16608. http://dx.doi.org/10.1029/2006GL026499

16. Bernard ATF, Ansorge IJ, Froneman PW, Bernard KS, Lutjeharms JRE. Entrainment of Antarctic euphausiids into the sub-Antarctic by a cold eddy. Deep-Sea Res Pt I. 2007;54(10):1841-1851. http://dx.doi.org/10.1016/j. dsr.2007.06.007

17. Pakhomov EA, Froneman PW, Ansorge IJ, Lutjeharms JRE. Temporal variability in the physico-biological environment of the Prince Edward Islands (Southern Ocean). J Marine Syst. 2000;26:75-95. http://dx.doi.org/10.1016/ S0924-7963(00)00041-5

18. Ansorge IJ, Lutjeharms JRE. The hydrography and dynamics of the ocean environment of the Prince Edward Islands (Southern Ocean). J Marine Syst. 2002;37:107-127. http://dx.doi.org/10.1016/S0924-7963(02)00198-7

19. Perissinotto R, Duncombe-Rae CM. Occurrence of anti-cyclonic eddies on the Prince Edward plateau (Southern Ocean): Effects on phytoplankton productivity and biomass. Deep-Sea Res Pt I. 1990;37:777-793.

20. Pakhomov EA, Froneman PW. Composition and spatial variability of macroplankton and micronekton within the Antarctic Polar Frontal Zone on the Indian Ocean during austral autumn 1997. Polar Biol. 2000;23:410-419. http://dx.doi.org/10.1007/s003000050462

21. Pakhomov EA, Chown SL. Appendix VI: Freshwater invertebrates of the Prince Edward Islands. In: Chown SL, Froneman PW, editors. The Prince Edward Islands: Land-sea interactions in a changing ecosystem. Stellenbosch: Sun Press; 2008. p. 398-399.

22. Pakhomov EA, McClelland JW, Bernard KS, Kaehler S, Montoya JP Spatial and temporal shifts in stable isotope values of the bottom-dwelling shrimp Nauticaris marionis at the sub-Antarctic archipelago. Mar Biol. 2004;144:317-325. http://dx.doi.org/10.1007/s00227-003-1196-3

23. Ryan PG, Jones MGW, Dyer BM, Upfold L, Crawford RJM. Recent population estimates and trends in numbers of albatrosses and giant petrels breeding at the sub-Antarctic Prince Edwards Islands. Afr J Mar Sci. 2009;31:409-417. http://dx.doi.org/10.2989/AJMS.2009.31.3.13.1001

24. Hofmeyr GJG, Bester MN, Makhado AB, Pistorius PA. Population changes in Subantarctic and Antarctic fur seals at Marion Island. S Afr J Wildl Res. 2006;36:55-68.

25. Williams AJ, Siegfried WR, Burger AE, Berruti A. The Prince Edward Islands: A sanctuary for seabirds in the Southern Ocean. Biol Conserv. 1979;15:59-71. http://dx.doi.org/10.1016/0006-3207(79)90015-6 
26. Crawford RJM, Cooper J, Dyer BM, Wolfaardt AC, Tshingana D, Spencer $\mathrm{K}$, et al. Population, breeding, diet and conservation of the Crozet shag Phalacrocorax [atriceps] melanogenis at Marion Island, 1994/95-2002/03. Afr J Mar Sci. 2003;25:537-547.

27. Crawford RJM, Ryan PG, Dyer BM, Upfold L. Recent trends in numbers of Crozet shags breeding at the Prince Edward Islands. Afr J Mar Sci. 2009;31:427-430. http://dx.doi.org/10.2989/18142320309504043

28. Crawford RJM, Whittington PA, Upfold L, Ryan PG, Petersen SL, Dyer BM, et al. Recent trends in numbers of four species of penguins at the Prince Edward Islands. Afr J Mar Sci. 2009;31:419-426. http://dx.doi.org/10.2989/ AJMS.2009.31.3.15.1003
29. Treasure AM, Moloney CL, Bester MN, McQuaid CD, Findlay KP, Best PB, et al. South African research in the Southern Ocean: New opportunities but serious challenges. S Afr J Sci. 2013;109(3/4), Art. \#a009, 4 pages. http://dx.doi. org/10.1590/sajs.2013/a009

30. Minister Edna Molewa declares Prince Edward Islands a Marine Protected Area [statement by the Department of Environmental Affairs]. 2013 Apr 13 [cited 2013 Nov 12]. Available from: http://www.polity.org.za/

31. Lombard AT, Reyers B, Schonegevel LY, Cooper J, Smith-Adao IB, Nel DC, et al. Conserving pattern and process in the Southern Ocean: Designing a marine protected area for the Prince Edward Islands. Antarct Sci. 2007;19:39-54. http://dx.doi.org/10.1017/S0954102007000077 